\title{
情報処理の立場から
}

\section{Data Base Design for Problem Presentation as a Real Time \\ Retrieval of Dynamic Health Situation in a Health Care System}

\author{
八 坂 敏 夫*
}

序

長期の健康管理を前提とし AMH Tのハードウェア特 性と情報処理ソフトウェアの可能性とを十分に生汃しう るシステム全体を考える，逆に，そのようなシステム全 体に対する medical requirement は何々であるが考 察すると，

1）定期的反復検診：可能な限り同一項目同一方法に よる組のテスト (Repetitive, Almost Periodic Examination with Almost Fixed Set of Examination Items)

2）それら 1 組のテストができるだけ同時的であると と (Almost Simultaneous Testing)

3）検診と検診の間の Follow up が可能なとと などがあげられる。

松岡の項の図 1 の経続的健康管理はこれを示す。健康 状態を示すいくつかの指標の組があるとすれば，それを 定期的検査扔よび診察によって促えたのが輪切りの状態 であり，輪切りが並んでいる状態が，その受診者の「健 康の動態的推移」である。

動態的推移の観察の, 1 組の指標に関する情報は, で きるだけ同時的であるのが望ましいのは，早朝空腹時と いう検査条件の設定と同様である。また，動態的推移の 観察には, 六カ月の反復期間の中間情報もできるだけ多

図 1

Concept of Medical Data Processing

1n PL Health Control System

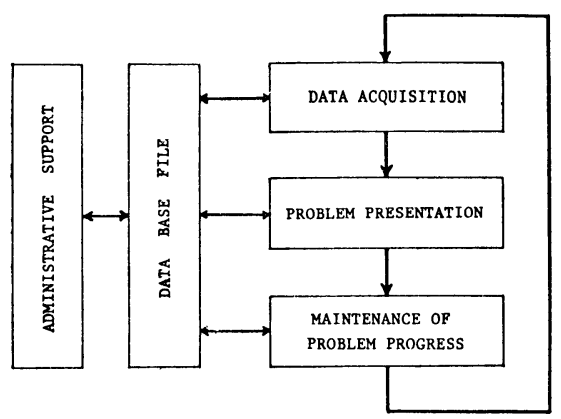

* $\mathrm{PL}$ Lディカル・データ・センター

\section{くもつのが望ましい。}

したがって，てのようなシステムに打いては，ある時 点で促えられた指標の情報は, 動態的推移に扔ける情報 であるから，その評価もまた，動態的推移の評価でなけ ればならない。

\section{1. 医学的要請の実施例}

\section{Problem Presentation System}

Health Care あるいは健康管理が医学として確立して

図 2

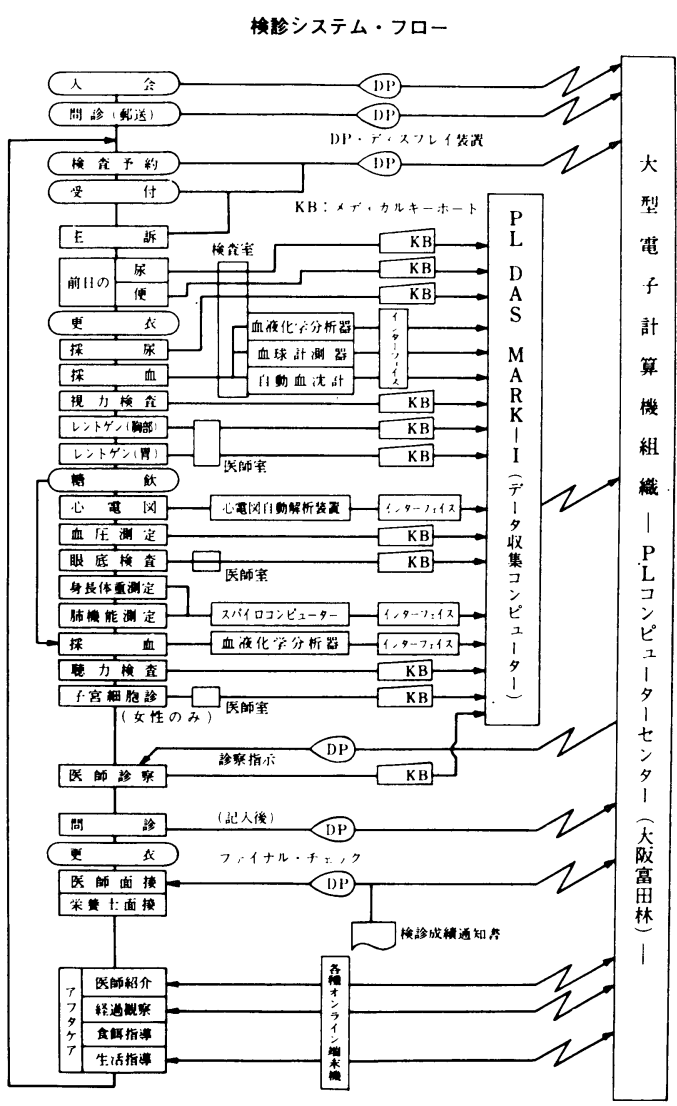

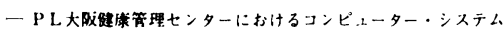


図 3

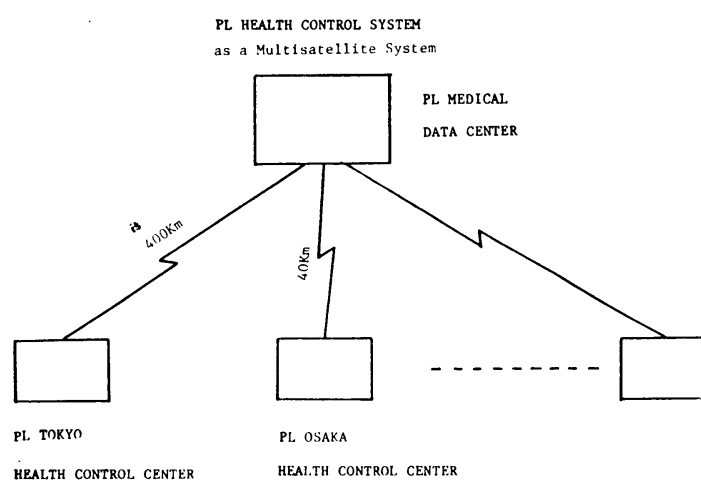

いるとはいえない以上 ${ }^{1)}$ ， 医師の判断を伴わない検診を 想定するととすらありうべきではない。むしろ，現在の Sick Care あるいは治病医学的知識が医師によって, 最 大限に活用されうるようなシステムを設計すべきである

（かく積み上げられた経験が将来の健康管理学の基盤と なる)。

しかし，反復検診のすべてのデータを検診担当医師の 前に提示したのでは，医師は医師本来の機能を果せなく なる2)。したがって，健康動態評価のために有意なデー 夕のみを選択して医師に問題提示するととが， P L 健康 管理システムに拈ける, medical data processing に 課せられた役割と考え，それを Problem Presentation System として把握した³)。そのもつべき要素扣よび要 素相互の関連は，図１亿示すごとくである。

図 4

\begin{tabular}{|c|c|c|c|c|c|}
\hline & & & Abnormal & lity List & \\
\hline$\star \star \star * \quad A B N O R$ & RMAL RESUL & $\star * \star$ & & $73 / 11 / 04$ & $01 / 02$ \\
\hline NAME: & & SEX: & FEMALE M & AARRIAGE: YES & AGE: 51 \\
\hline & $73 / 11$ & $73 / 05$ & $72 / 08$ & & $73 / 11$ \\
\hline PROT.URIA. & + & -- & -- & TONOMET (R) & $21.0+$ \\
\hline MICRO-RBC & $\langle 20 / \mathrm{F}+$ & $<1 / \mathrm{F}-$ & $<2 n / F-$ & TONOMET (L) & $21.0+$ \\
\hline MICRO-WBBC & $<2 / F-$ & $<5 / F+$ & $<2 / F-$ & ECG RHYT.1 & 50- \\
\hline BACT.URIA & -- & + & H & ECG PATN.1 & $03+$ \\
\hline A/G RATIO & $2.0+$ & $1.6-$ & $1.7-$ & ECG PATN. 2 & $25+$ \\
\hline HCT & $36.0-$ & $37.5-\mathrm{A}$ & $31.5+$ & DUOD.DX.OT & SUSP+ \\
\hline MCV & 91- & $94-$ & $84+$ & $\mathrm{LDH}$ & $185.0+\mathrm{A}$ \\
\hline $\mathrm{MCH}$ & $29.5+$ & $31.9-$ & $32.1-$ & SGOT & $52.0-$ \\
\hline MCHC & $32.5-$ & $33.9-$ & $38.1+$ & T.PROTEIN & $8.00-$ \\
\hline $\mathrm{BP}$ (DIAST) & 96- & 92-A & 70- & ALBUMINE & $5.30+$ \\
\hline OP-SCAR & PERt & PER+ & -- & & \\
\hline SPOND.DEF & + & + & -- & & \\
\hline BULBUS DEF & + & -- & -- & & \\
\hline CARD ARCH & -- & -- & L4t & & \\
\hline AORT DILAT & + & SUSP+ & -- & & \\
\hline OBESITY & $126.3+$ & $118.6+$ & $122.6+$ & & \\
\hline C/T RATIO & 47- & $50+$ & $52+$ & & \\
\hline
\end{tabular}

図 5

\begin{tabular}{|c|c|c|c|c|c|c|c|}
\hline$\underset{\text { T...10 }}{\text { 月 }}$ & 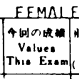 & 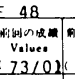 & 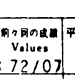 & $\begin{array}{l}7 \\
\text { Meen }\end{array}$ & 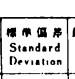 & $\begin{array}{l}\qquad \star x \\
\text { Masimum }\end{array}$ & $\mid \begin{array}{c}\text { (2) } \\
\text { Minimum } \\
\text { M. } \\
\end{array}$ \\
\hline 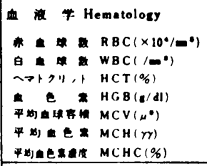 & $\begin{array}{r}395 \\
6800 \\
37.5 \\
12.1 \\
95 \\
30.6 \\
32.3\end{array}$ & $\begin{array}{r}395 \\
5400 \\
38.0 \\
12.9 \\
96 \\
31.9 \\
33.2\end{array}$ & $\begin{array}{r}406 \\
6000 \\
34.0 \\
13.0 \\
84 \\
32.0 \\
38.2\end{array}$ & $\begin{array}{r}400 \\
5900 \\
37.1 \\
12.6 \\
9.3 \\
31.5 \\
34.1\end{array}$ & $\begin{array}{r}5 \\
500 \\
1.8 \\
0.5 \\
0.5 \\
2.9\end{array}$ & $\begin{array}{r}406 \\
6800 \\
39.0 \\
13.2 \\
327 \\
32.5 \\
38.2\end{array}$ & $\begin{array}{r}395 \\
5309 \\
34.0 \\
11.9 \\
84 \\
30.1 \\
32.3\end{array}$ \\
\hline $\begin{array}{l}\Delta \times E C G \\
\quad \text { Findinge }\end{array}$ & 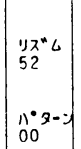 & $\begin{array}{l}12 x^{*} \iota \\
50 \\
109-\cdot \\
00\end{array}$ & 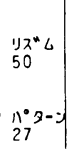 & & & & \\
\hline $\begin{array}{l}\text { 心 } \quad \text { \& PCG } \\
\text { R Findings }\end{array}$ & & & 0050 & & & & \\
\hline 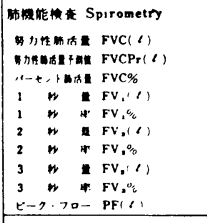 & $\begin{array}{l}1.73 \\
2.48 \\
59.7 \\
1.43 \\
82.7 \\
1.67 \\
93.0 \\
1.69 \\
97.7 \\
5.23\end{array}$ & $\begin{array}{l}2.30 \\
2.49 \\
92.1 \\
1.37 \\
59.6 \\
1.54 \\
67.0 \\
1.61 \\
70.0 \\
4.08\end{array}$ & $\begin{array}{l}1.90 \\
2.47 \\
76.0 \\
1.47 \\
77.0 \\
1.69 \\
88.9 \\
1.81 \\
95.0 \\
3.90\end{array}$ & $\begin{array}{l}1.81 \\
2.50 \\
72.1 \\
1.34 \\
74.6 \\
1.53 \\
84.9 \\
1.61 \\
89.6 \\
4.33\end{array}$ & $\begin{array}{r}0.24 \\
0.02 \\
9.8 \\
0.03 \\
7.1 \\
0.14 \\
3.11 \\
9.1 \\
1.31\end{array}$ & $\begin{array}{ll}4 & 2.30 \\
2 & 2.54 \\
8 & 92.1 \\
3 & 1.4 \\
1 & 82 . \\
0 & 1.64 \\
4 & 93.6 \\
1 & 1.81 \\
1 & 97.4 \\
1 & 6.40\end{array}$ & 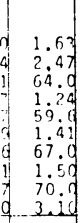 \\
\hline 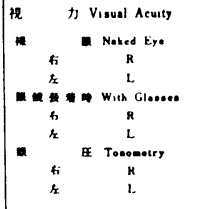 & $\begin{array}{l}1.2 d \\
1.50 \\
-\mathrm{Nd} \\
-\mathrm{nd} \\
16.0 \\
17.0\end{array}$ & $\begin{array}{c}1.00 \\
0.90 \\
-111 \\
-4 n \\
14.0 \\
17.0\end{array}$ & $\begin{array}{r}0.9 d \\
0.9 d \\
-N d \\
-N d \\
17.0 \\
17.0\end{array}$ & $\begin{array}{l}0.38 \\
0.32 \\
0.90 \\
16.8 \\
17: 8\end{array}$ & $\begin{array}{l}0.13 \\
0.30 \\
0.0 d \\
2.5 \\
1.7\end{array}$ & $\begin{array}{l}1.20 \\
1.50 \\
0.90 \\
21.0 \\
21.0\end{array}$ & $\begin{array}{l}0.80 \\
0.50 \\
0.90 \\
14.0 \\
16.0\end{array}$ \\
\hline $\begin{array}{rl}\text { H) } & \leqslant \text { Audiometry } \\
125 & H Z \text { (db) } \\
250 & H Z \text { (db) } \\
500 & H Z \text { (db) } \\
1000 & H Z \text { (db) } \\
2000 & H Z \text { (db) } \\
0000 & H Z \text { (db) } \\
8000 & H Z \text { (db) } \\
\end{array}$ & {$\left[\begin{array}{ll}4(\mathbf{R}) & 2 \\
20 & 40 \\
40 & 20 \\
40 & 20 \\
40 & 40 \\
40 & 40 \\
40 & 40 \\
40 & 40\end{array}\right.$} & $\begin{array}{ll}(R) 4 & 11 \\
40 & 40 \\
40 & 40 \\
40 & 40 \\
40 & 40 \\
40 & 40 \\
40 & 40 \\
40 & 40 \\
\end{array}$ & $\begin{array}{ll}40 & 40 \\
40 & 40 \\
40 & 40 \\
40 & 40 \\
40 & 40 \\
40 & 40 \\
40 & 40 \\
\end{array}$ & & & & \\
\hline
\end{tabular}

Data Acquisition は，いわゆるA MHTによる。ほとんどのデータが, 人的誤りを最少にするためにオンライ ンで，データ収集用のサテライト・コ ンピュータに入力される（図2）。サ テライトは, 東京センターは I B M 1800，大阪センターは，われわれ自身 で Total Input System として開発し た PL-DAS MARK-I である4)。

サテライトに収集されたデータは， 通信回線により PL Medical Data Center の中型コンピュータ（現在の ととろ I B M370/135，240K B）に送 られる。すなわち，P L 健康管理シス テムは, 図3のでとく multi-satellite システムである。

データ・センターでは，独自に開発 
図 6

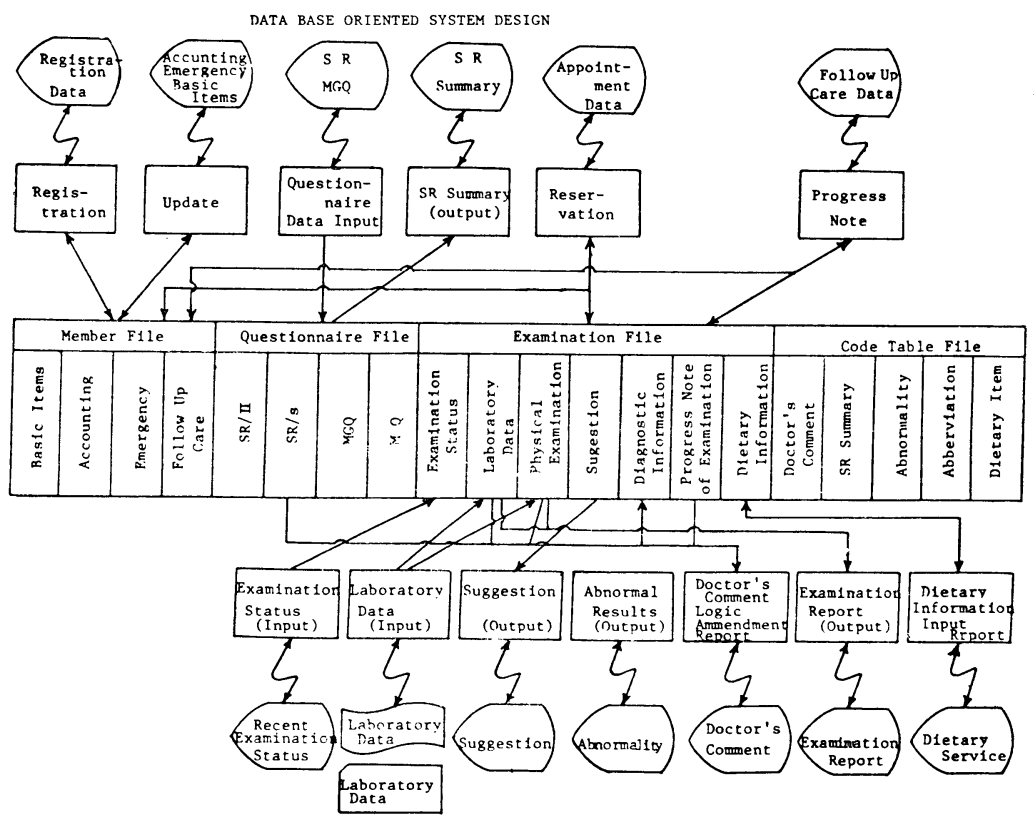

したデータ・ベース・デザインのソフトウェアでProblem

Presentation も可能にするデータ解析を行なう5)。

第 1 は直接的に問題提起をする類, すなわち System Review Summary (松岡: 図3) Abnormality List （図 4)をフィード・バックするもの。Abnormality List は, いわゆる正常值を越えた検査項目, 異常所見のリス トで, 最近 3 回の検診中 1 回でも異常があれば, 経過観 察のため 3 回分の成績すべてを出力する（十異常, 一正 常）。さらに，項目でとの母集団に関して，連続する 2 回の計測值の間の変動の平均, および標準偏差が計算さ れていて, ての平均 +2 S. D. の值を越える変動が前回 の計測との比較において知られた場合は $\mathrm{A}$ (上昇) $\mathrm{D}$ (下 降）の符号を付して担当医師への警告とする。てれは， 計測值がいわゆる正常の範囲内にあっても起とりうるも ので, 個人の正常值の substitute としている6)。検診 成績全体のレポートは, さらに，過去すべての成績の abstract, すなわち, 平均值, 標準偏差, 最大值, 最少 值を付加する（図 5)。

第 2 は, 医師団のコンセンサスによるロジックでデー 夕解析する類である。第 1 が経時的側面を主としたに対 し, 第 2 は, System Review, 当日 complaints, 検査 条件などまでも含めたデータ相互の関係を主とするもの で, 診察担当医師や面接担当医師への suggestion（松 岡：図4）などが含まれる。
医師の所見, 診断, システムの提示に対する訂正加除, 面接記録, Follow up データなど, すべてデータ・ベー スに記録される(図 6)。

\section{2. 今後の諸問題}

上記システムは, 健康動態の把握に十分とはいえな い。今後の第 1 の問題は, てれを P.O.S.に整備する (図 7)ととである。従来もP.O.ではあったが，問題別 リトリーブに欠けている7。

第 2 の問題は, データ・ベースを活かし, 性別年令別 などによる母集団の分割をすすめ, そのメッシュの中で の分布を正確に把握して, 個人の位置づけを明確化する 問題である。”ッシュの要素として今後は, environment や mental behavior ${ }^{8)}$ を含めたい。

第 3 の問題は個人の正常值の問題である, ${ }^{9,0)}$ 。図 8 は 本システムのデータ・ベース・ファイルを分析するとと によって得られた知見の一つであるが, 図の上半分の点 線は, 男子全年令のコレステロール分布, 実線は男子 40 〜 45才のコレステロール分布で両者の間であまり差はな い。しかし, 眓の下半分は, 男子40 45才のうちで, 検 診をすでに 6 回〜 7 回反復したもののみを抽出し, 個人 でとに，その検査值をスペクトル状にプロットしたもの であり，大きな個人差がみられる（左から個人の id., 検診回数, 個人の平均, s.d., c. v., 等を示す)。いわ 
日本自動化健診システム研究会第 2 回総会より

図 7

\begin{tabular}{|c|}
\hline 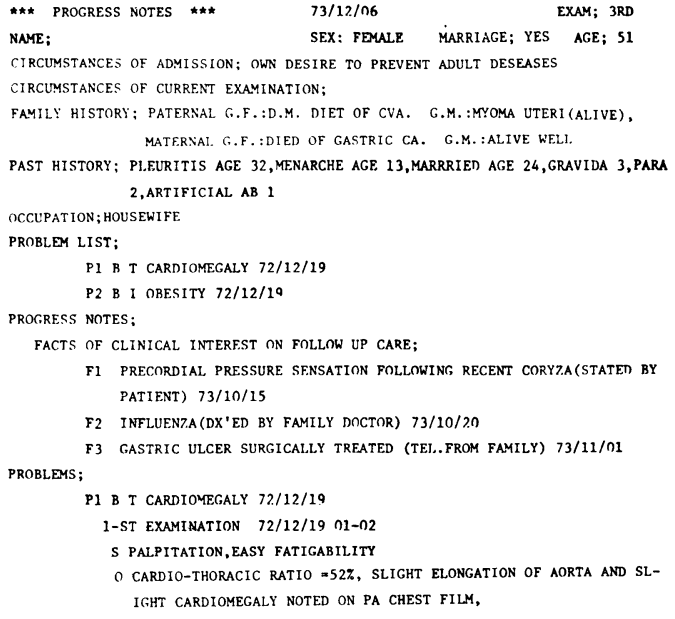 \\
\hline
\end{tabular}

図 8 Frequency

CHORESTEROL (MALE)

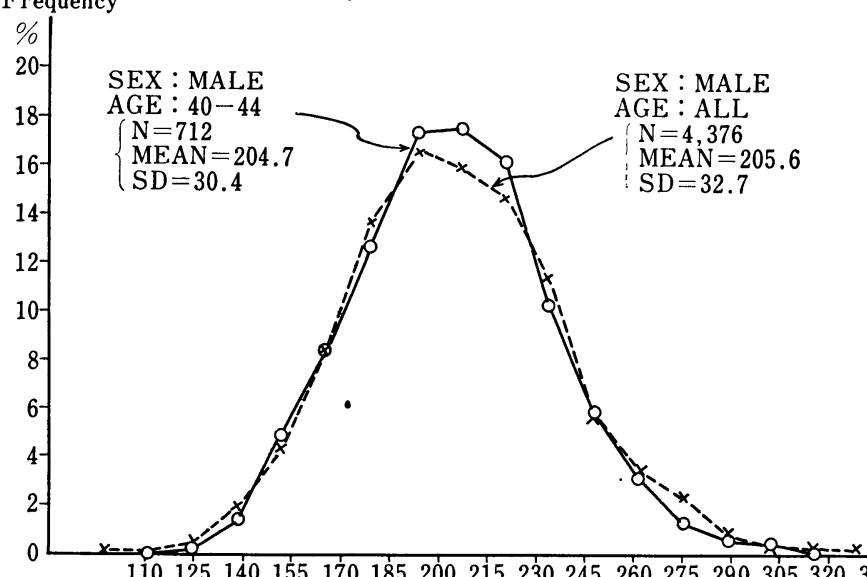

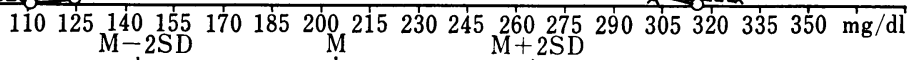
143.9

$130.2-0-0-\frac{2}{205.6}$

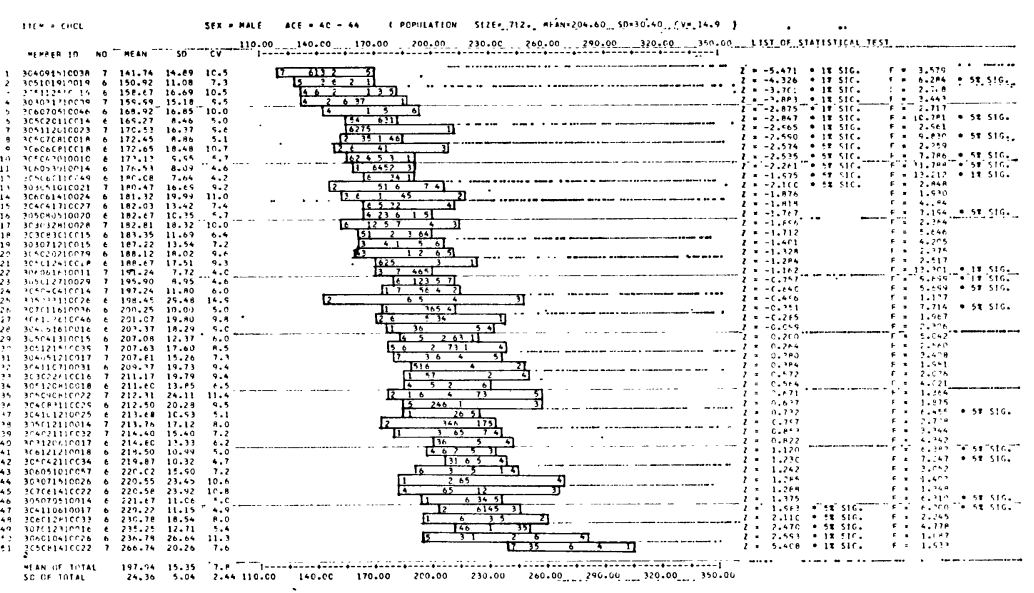


図 9

Prequency D1stribution of S.D. (Cholestero1)
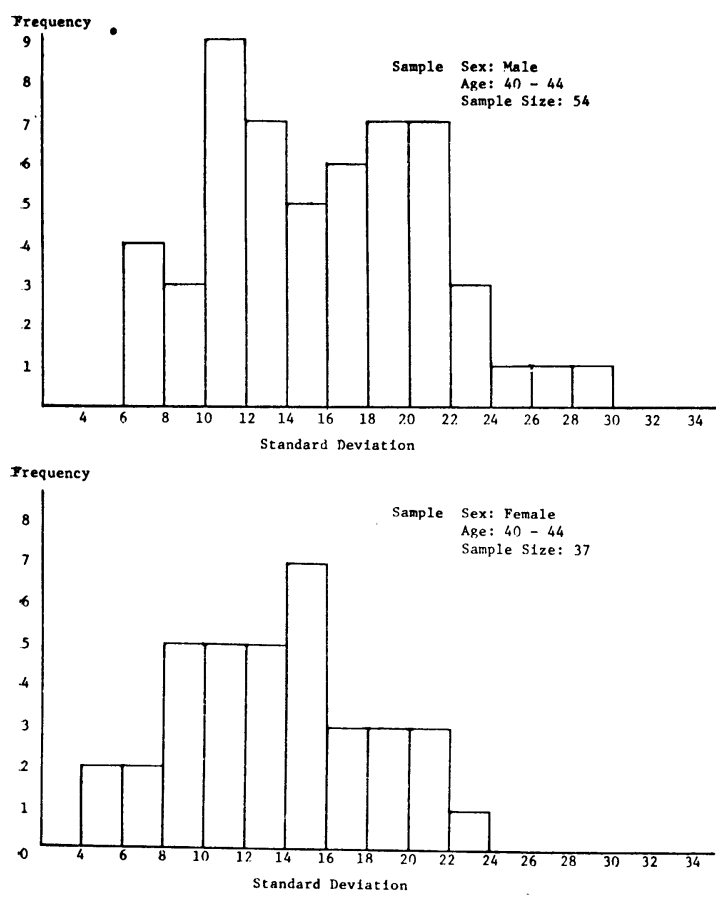

ゆる normal range に比し, 個人の変動幅は小さく, 変動幅の間の差は大きい。図 9 は個人の s.d. の分布を 示す。集団の s.d. 30.4 亿対し個人の s.d. は10 20に 集まる形でばらついている。下半は，女子のそれで集団 のs.d.は27.7であった。個人の変動幅が集団のそれに 近いといわれるトータル・プロティンについても，ほぽ 同様の所見が得られた。

個人の計測値の中には，個人自身のデー夕集団から得 られる $\mathrm{m} \pm 2 \mathrm{~s} . \mathrm{d} .{ }^{11)}$ を越えるものがある。むろんその多 くは，いわゆる normal range の中にある。かかる值に 対する臨床的意義の追求は，図 8 が示すような個人の值 の変動の様相に対して，その正常值を如何に設定するか の問題とともに，今後の研究課題である ${ }^{12)}$ 。

情報処理としての第 4 の問題は，検査值を個々に univariate としてだけでなく，1組の multivariate とし て取り扱う問題である ${ }^{13)}$ 。

第 5 の問題（結語）は，第 2 第 4 の成果を現在のデ シジョン・テーブルに組み入れてロジックを一層成長さ

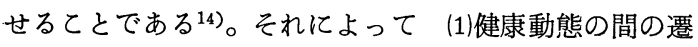
移確率から ${ }^{15)}$, 予測問題も比較的取り扱い可能な問題に 帰着するととができるかもしれないし，(2)多次元的要素 を要約する方法が発見できれば，あるいは近い将来，項
目の限定，コスト・ダウン，大衆化といった道が開ける かもしれない。

\section{文献}

1) Culter, J.L.: Evaluation of Periodic Health Examination Programs, Informatique Médicale Colloque IRIA, Tome 1-Toulouse 5-9 Mars, 1973, pp. 9 15

2) Krasnoff, S.O.: Computers in Medicine, Charles C. Thomas, Publishers, Springfield, Ill, 1967 (大久 保, 八坂共訳）

3）八坂敏夫, 他: Multiphasic Health Screening におけ るリアルタイム情報検索，MEDIS，大阪，1973年 10月。

4) Yasaka, T.: Health Check-up System at Osaka PL Medical Department, Informatique Médicale Colloque IRIA, Tome 1-Toulouse, 5-9 Mars, 1973, pp. $31 \sim 43$

5）八坂 敏夫：P L 健康管理システムに打けるデータ・センタ 一を中心とした医療情報処理, P L 医学, 40 (3), pp. 8 16, 1972

6) Yasaka, T.: PL Health Control System as a Problem Oriented Medical Data Processing, Informatique Médicale Colloque IRIA, Tome 1-Toulouse, 5-8 Mars 1974, pp. 291 320

7) Schultz, J. R., Cantrill, S. V., Morgan, K.G.: An Initial Operational Problem-Oriented Medical Record System-For Storage, Manipulation and Retrieval of Medical Data, Chapter 27, in The Problem Oriented System, Edited by J. Willis Hurst and H. Kenneth Walker, Medicom Inc., New York, 1972

8) Friedman, M. and Rosenman, Ray H.: Type A Behavior and Your Heart, Alfred A. Knopf, New York, 1974

9) Davies, D.F.: The Critical Issue: Normal or Normative?, in Health Evaluation, an entry to the health care system, Edited by Dean F. Davies and James B. Tchobanoff, Intercontinental Medical Book Corp., New York, 1973, pp, 45 54

10）河合 忠: 正常值の考方方, 正常值と異常の間 I（日野原 重明, 河合 忠編集), 中外医学社, 1972

11) 土肥一郎: 平均值抢よび正常值の推定に関する 2,3 の注 意事項, 正常値と異常值の間 I（日野原重明，河合 忠編集）

12）北村 元仕: 正常值とは何か, 日本臨床, 29(1), 增刊, 186 $\sim 192,1971$

13) Grams, R. R. et al : Laboratory Data Analysis System: Section III-Multivariate Normality, Am. J. Clin, Pathol. 58; 188 200, 1972

14) Warner, H. R. et al: HELP-A Program for Medical Decision-Making, Comp. Biomed. Res., 5; 65 74, 1972

15) Booth, T.L.: Sequential Machine and Automata Theory, John Wiley and Sons, Inc., New York, 1968 